\title{
Relationship Between Training and Internal Staffing with Employee Work Performance (A Study at the Public Works Department of Sukabumi Regency)
}

\author{
Budi Rismayadi ${ }^{1}$, Mumun Maemunah ${ }^{2}$, Citra Savitri ${ }^{3}$ \\ 1, 2, ${ }^{3}$ Faculty of economic and business, University of Buana Perjuangan Karawang, Indonesia \\ Email: budi.rismayadi@ubpkarawang.ac.id
}

\begin{abstract}
The purpose of this study was to determine the relationship of training in improving employee performance and internal staffing relationships in improving employee performance and how the relationship between training and internal staffing in improving employee performance. The research method used is a verification method of research with multiple linear regression models, processing data using multiple correlation analysis and using the $\mathrm{F}$ test and t-test. The total population taken was 58 permanent employees, and a random sample of 50 respondents and the data collection technique used a questionnaire with a Likert scale. From the calculation of the multiple correlation coefficient between training and employee performance resulted in a positive number of 0.98 which means that employee performance is greatly influenced by training. This shows the relationship between training with employee performance is solid. These results are supported by significant test results $t(t$ arithmetic $=1.36>=1.30$ ). This means that training makes a meaningful contribution; while internal staffing (tcount $=0.009<$ ttable $=1.30$ ) showed a less significant relationship in improving employee work performance, even though it had a correlation coefficient ( $r y 2=0.98$ ). Training and internal staffing on employee performance have a solid relationship, as evidenced by a variance of $96.52 \%$. And the remaining $3.48 \%$ is caused by other factors.
\end{abstract}

Keywords: Training, Internal Staffing, Job Performance

\section{A. INTRODUCTION}

In the current era of globalization, skills and knowledge are basic things that must be possessed by everyone to build progress. This is of course, with appropriate education and training, so that in the future human development will be created that is dynamic and in harmony with the expected goals (Terpstra \& Rozell, 1993).

For full human development to run smoothly and indeed lead to the achievement of the expected goals, it is necessary to determine the general pattern of long-term growth carried out in stages with the primary objective being to create a strong foundation for the Indonesian people to grow and develop in a directed and educated manner (Stevens \& Campion 1999). Education is all efforts to foster the personality and develop the ability of Indonesian people, physically and spiritually which lasts a lifetime, both inside and 
outside the school, in the context of building the unity of Indonesia and prosperous society based on Pancasila.

Exercise is a part of education that applies in a relatively short time with methods that prioritize practice over theory. One way to achieve this is by conducting training and internal staffing. However, training and internal staffing must continue to be carried out because training and internal staffing are very beneficial both for agencies and for employees. Gomes (2012), states that: Training is an attempt to influence the performance of workers in a particular job that is their responsibility, or a job that is related to their work. Meanwhile, according to Sikula (2010), states that: Exercise is a short-term educational process using systematic and organized procedures, through which operational employees learn knowledge of artistry techniques and expertise for specific purposes. The internal staffing according to Dessler (2012): Human resources development (HRD) is planned, a continuous effort by management to improve competency level and organizational performance which means: Internal staffing is a planned and continuous effort to improve employee competence and organizational performance.

There are several benefits of training, and internal staffing, including benefits for agencies, include having employees ready to carry out their work so that with such employees, agencies can achieve their goals more easily. At the same time, the benefits for employees themselves are that they can develop attitudes, behaviours behaviour, skills and additional knowledge about the work (Kim \& Ployhart ,2014). This will improve the work performance of the employees concerned so that they can support the achievement of agency goals effectively and efficiently. Employees are valuable assets for agencies because the progress of an agency or organization is in the hands of employees (human resources). To maintain these assets, the agency or organization needs to carry out training and internal staffing to anticipate and solve problems both current and future. However, even though training and internal staffing are held, it is not guaranteed that the issues can be answered so that training and internal staffing are not sufficient and efficient (Gong, 2003).

An organization is undoubtedly required to continue to strive to manage its human resources so that the goals and expectations of the organization can be achieved following what is desired, (Rismayadi \& Maemunah, 2016) states that the management of human resources intended is that companies must be able to unite perceptions or the perspective of employees and leaders of the company to achieve company goals, among others through the formation of a great working mentality with high dedication and loyalty to their work, providing work motivation, guidance, direction and proper coordination in working by a leader to his subordinates. 
Gomes (2009), argues: to be effective, training and internal staffing must be the right solution to organizational problems, namely that the training must be intended to correct skills shortages. To increase learning efforts, employees must recognize the need to obtain new information or learn new skills, and the desire to learn must be maintained. Whatever the work standards set by the organization, employees must not be disappointed by trainers who demand too much or too little.

Improving work performance, it is also essential to pay attention to job satisfaction and relationships between employees (Rismayadi, 2018) so that training conducted by an organization can be carried out optimally and able to improve the performance of its employees.

Sukabumi Regency Public Works Department is an agency that is engaged in services where the agency in providing its services strives to make the community feel satisfied, which of course is highly dependent on the service provided by its employees.

\section{B. LITERATURE REVIEW Definition of Training}

To get a clearer picture of the meaning of training, the following is put forward by some expert understanding, including Gomes (2009) stating that: Training is an attempt to influence the performance of workers at a particular job that is their responsibility, or a work that has to do with work. Meanwhile, according to Andrew Sikula (2009), states that: Exercise is a short-term educational process using systematic and organized procedures, through which operational employees learn knowledge of artistry techniques and expertise for specific purposes.

So training is only useful in situations where employees lack skills, knowledge, exercise is not intended to replace inadequate selection criteria, inaccurate job design, or insufficient organizational rewards. Training is more as a means aimed at efforts to reduce negative impacts due to lack of education, limited experience, or lack of confidence from certain members or groups according to Gomes (2009), so that with a training program in an organization or the agency allows to improve the mastery of skills and technical implementation of specific, detailed and routine work. The exercise prepares employees to do work in progress or at present. Sikula in Hasibuan (2012), states that: Exercise is an effort to increase the knowledge and expertise of an employee to do a specific job."

From the opinions above, it can be concluded that education has a broader meaning than training related to a particular approach. Education is related to increasing general knowledge and understanding of our environment as a whole. Education is more theoretical, while the practice is practical. 
Education and training are a unity that cannot be separated from each other and is a tool sought by the leadership of the agency to improve the skills and knowledge of employees to be able to carry out their work correctly, workplace passion can be increased and is expected to be able to improve performance or work performance employee.

Training is intended to cover the shortcomings of skills, knowledge, and how to carry out work following the work objectives that have been determined with a shortterm work orientation meaning that training is only prepared to answer the problems being faced at present.

\section{Definition of Internal Staffing}

Internal staffing is defined by Milkovich \& Boudrea (2007), as Employee development refers to human resources activities designed to enhance the value of employees after they have joined the organization. It encompasses internal staffing, which involves moving people between jobs and work roles within the organization. It also includes employee training which consists of giving employers' experiences designed to foster learning.

Internal staffing is related to human resource activities that are designed to increase employee value after they join the organization. Internal staffing consists of internal staffing which includes the movement of employees between positions and work roles within the organization. Internal staffing also provides training that is designed to give experience to employees who can encourage the learning process. Understanding the value as summarized from Milkovich \& Boudreau (2007), is how many employees contributions to the achievement of company goals and donations can be given through work performance generated. Another definition of internal staffing stated by Cascio, (2005) namely: Human resources development (HRD) can be defined as a set of systematic and planned activities designed by an organization to provide its members with the necessary skills to meet an employee's joint an organization and continue throughout his or her career. HRD programs must respond to job changes and integrate the long term plans and strategies of the organization to ensure the efficient and effective use of resources.

Internal staffing is defined as a planned activity and is designed to give its members the expertise needed to meet the demands of current and future work. This activity began in his career. Internal staffing employees must respond to changes in work, and be integrated with company plans and strategies to ensure the efficiency and effectiveness of the use of human resources; whereas according to Dessler (2002): Human resources development (HRD) is planned, continuous effort by management to improve competency level and organizational performance. 
Internal staffing is a planned and continuous effort to improve employee competence and organizational performance.

From the three definitions above it is concluded that internal staffing is an activity in the field of human resources that is planned, systematic, and continuously aimed at improving employee and company work performance through increasing employee competence by making transfers between positions or work roles within the company (internal staffing) and training so that employees can meet current and future job demands. Internal staffing employees must be able to respond to changes in work and be integrated with corporate planning and strategy.

\section{Definition of Job Performance}

The achievement of company goals will depend on the work performance of the employees of the company. The definition of work performance is stated below. Job performance is something that is done or service products produced/given by a person or an entire organization (Dharma, 2001). Performance is defined as the record of outcomes produced on a specified job function or activity during a specified period (Bernardin \& Russel, 2008).

Achievement is defined as the number of outputs that result from certain functions or activities over a specified period. From the above definition, it can be concluded that work performance is several outputs/outputs produced by individuals or organizations of specific functions or activities during a specified period. Meanwhile, according to Hasibuan (2012) that: Job performance is the work achieved in carrying out work tasks in carrying out tasks assigned to him based on skill, experience, and sincerity as well as time. It can be concluded that work performance is the result of work and behaviour achieved by someone in terms of completing their duties.

\section{Measures of Work Performance}

Plippo (2011) provides an overview of the work performance factors assessed for personnel who are paid hourly, namely:

1. Quality of work consisting of accuracy, skill, accuracy, and tidiness

2. Work quantity is output

3. Resilience consists of: following orders, habits, safety, initiative, timeliness, and attendance

4. Attitudes include: Towards change, work and coworkers, and cooperation

Hasibuan (2009) also said that work performance is a combination of three essential factors namely the ability and interest of a worker, the ability and acceptance of task delegation explanation in the role and motivation level of a worker, the higher the 
three factors above, the greater the work performance of the employee concerned, and mentions some of the elements assessed in work performance, namely:

1. Loyalty, reflected by the state of employees guarding and defending the organization inside and outside the work of undermining people who are not responsible.

2. Job performance, assessing the work results both in quality and quantity that can be produced by the employee from the job description.

3. Honesty, startling honesty in work that fulfils the agreement both for himself and for others as to his subordinates.

4. Discipline, assess employee discipline and comply with existing regulations and do the work according to the instructions given to him.

5. Creativity, assessing the ability of employees in developing creativity to complete their work, so that its work is more efficient and valuable.

6. Cooperation, assessing the willingness of employees to excel and cooperate with other employees both vertically and horizontally inside and outside of work.

7. Leadership, assessing the ability to lead, influence, have a strong personality, respected, authoritative, and can motivate others or subordinates.

8. Personality, assessing behaviour, politeness, liking, giving a pleasant impression, showing the right attitude and sympathetic and reasonable appearance of the employee.

9. The initiative, assess the ability to think rationally and based on his effort to analyze, evaluate, create, give reasons, get conclusions, and make decisions on solving the problems he faces.

10. Skills/skills, assess employee skills in uniting, harmonizing various elements with all involved in policymaking and management situations.

11. Responsibility, assessing the willingness of employees to be responsible for their policies, work and work results, facilities and infrastructure used behaviour and work results of their subordinates.

The elements of employee performance that are to be assessed by each organization or agency are not always the same, but basically, the elements of being evaluated include the things above.

\section{METHODOLOGY}

The research method used is a verification method of research with multiple linear regression models, processing data using multiple correlation analysis and using the $\mathrm{F}$ test and t test. This study uses three variables, namely independent variables consisting of $X_{1}$ variables (training) and $X_{2}$ independent variable (internal staffing), while the dependent variable is the $\mathrm{Y}$ variable (employee work performance). The population was 
58 permanent employees, and 50 respondents were randomly selected as well as data collection techniques using a questionnaire with a Likert scale. From the population above will be chosen based on a stratified random sample, then to determine the sample size is based on the sample size formula (Umar, 2001) as follows:

$$
\mathrm{n}=\frac{N}{\left(1+e^{2} N\right)}
$$

Notation

$\mathrm{n}$ = number of sample sizes used by the correspondent

$\mathrm{N}=$ number of population

$\mathrm{e}=$ Error factor, taken $5 \%$

In this case, a population of 58 people with an error factor of $5 \%$, then the total sample

size:

$$
\mathrm{n}=\frac{58}{\left(1+(0,05) .^{2} 58\right)}=50 \text { respondent }
$$

\section{RESULT AND DISCUSSION}

To find out the magnitude of the relationship between training and internal staffing in improving employee performance, regression analysis and multiple correlations are used. This can be seen from the answers to the questionnaire given to 50 respondents of Sukabumi District Public Works Department employees. (for more details, the authors present in the form of a table). The attitude measurement method that is analyzed based on the results of the questionnaire that has been filled out by respondents is outlined in the form of positive and negative questions with five alternatives available. After the data collected, the next step is to conduct an analysis that tests each respondent; each respondent has a score from each questionnaire. The following are the results:

$\mathrm{Y}$ multiple linear regression model for $\mathrm{X}_{1}, \mathrm{X}_{2}$ will be estimated by

$$
\hat{Y}=\mathrm{a}_{0}+\mathrm{a}_{1} \mathrm{X}_{1}+\mathrm{a}_{2} \mathrm{X}_{2}
$$

with the coefficients a0, $\mathrm{a}_{1}$, and a2 calculated using the formula:

$$
\begin{gathered}
\mathrm{a}_{0}=\bar{Y}-\mathrm{a}_{1} \bar{X}_{1}-\mathrm{a}_{2} \bar{X}_{2} \\
\mathrm{a}_{1}=\frac{\left(\sum X_{2 i}^{2}\right)\left(\sum X_{1 i} Y_{i}\right)-\left(\sum X_{1 i} X_{2 i}\right)\left(\sum X_{2 i} Y_{i}\right)}{\left(\sum X_{1 i}^{2}\right)\left(\sum X_{2 i}^{2}\right)-\left(\sum X_{1 i} X_{2 i}\right)^{2}} \\
=\frac{(57360)(116497)-(48204)(137300)}{(41142)(57360)-(48204)^{2}}
\end{gathered}
$$




$$
\begin{aligned}
& =14,7399501=14,74 \\
\mathrm{a}_{2} & =\frac{\left(\sum X_{1 i}^{2}\right)\left(\sum X_{2 i} Y_{i}\right)-\left(\sum X_{1 i} X_{2 i}\right)\left(\sum X_{1 i} Y_{i}\right)}{\left(\sum X_{1 i}^{2}\right)\left(\sum X_{2 i}^{2}\right)-\left(\sum X_{1 i} X_{2 i}\right)^{2}} \\
& =\frac{(41142)(137300)-(48204)(116497)}{(41142)(57360)-(48204)^{2}} \\
& =0,075166589=0,08 \\
\bar{Y}^{2} & =\frac{\sum Y_{i}}{n}=\frac{4121}{50}=82,42 \\
\bar{X}_{1} & =\frac{\sum X_{1 i}}{n}=\frac{1416}{50}=28,32 \\
\bar{X}_{2} & =\frac{\sum X_{2 i}}{n}=\frac{1672}{50}=33,44 \\
\mathrm{a}_{0}= & \bar{Y}-\mathrm{a}_{1} \bar{X}_{1}-\mathrm{a}_{2} \bar{X}_{2} \\
= & 82,42-14,74(28,32)-0,08(33,44) \\
= & -337,70
\end{aligned}
$$

then multiple $\mathrm{Y}$ linear regression for $\mathrm{X}_{1}$ and $\mathrm{X}_{2}$ is

$$
\hat{Y}=-337,70+14,74 \mathrm{X}_{1}+0,08 \mathrm{X}_{2}
$$

So it can be concluded that the multiple linear regression model above has:

$$
\mathrm{a}_{0}=-337.70 ; \text { is an intercept }
$$

$\mathrm{a}_{1}=14.74$; is the magnitude of the effect of $\mathrm{X}_{1}$ on $\mathrm{Y}$, if $\mathrm{X}_{2}$ is constant and $\mathrm{X}_{1}$ goes up by one unit.

$a_{2}=0.08$; is the magnitude of the effect of $X_{2}$ on $Y$, if $X_{1}$ is constant and $X_{2}$ goes up by one unit. 
Based on Table 4.45 we can calculate the standard error of estimation in multiple linear regression, namely:

$$
\begin{aligned}
s_{y .12}^{2} & =\frac{\sum\left(Y_{i}-\hat{Y}_{i}\right)^{2}}{n-k-1} \\
& =\frac{237286}{50-2-1} \\
& =\frac{237286}{47} \\
& =5048,64
\end{aligned}
$$

Number of regression squares : $\mathrm{JK}_{\mathrm{reg}}=\mathrm{a}_{1} \sum X_{1 i} Y_{i}+\mathrm{a}_{2} \sum X_{2 i} Y_{i}$

$$
\begin{aligned}
& =14,74(116497)+0,08(137300) \\
& =1717165,78+10984 \\
& =1728149,78
\end{aligned}
$$

Number of residual squares : JK $\mathrm{J}_{\text {res }}=\sum\left(Y_{i}-\hat{Y}_{i}\right)^{2}$

$$
=237286
$$

Then the F statistic is : $\mathrm{F}_{\text {count }}=\frac{J K_{\text {reg }} / k}{J K_{\text {res }} /(n-k-1)}$

$$
\begin{aligned}
& =\frac{1728149,78 / 2}{237286 / 47} \\
& =\frac{864074,89}{5048,64} \\
& =171,15
\end{aligned}
$$

From the list of $\mathrm{F}$ distributions with numerator $\mathrm{dk}=2, \mathrm{dk}$ denominator $=47$ and $\alpha$ $=0.05$, we get $F_{\text {table }}=3.20$. Because $F_{\text {count }}>F_{\text {table }}$ can be concluded that the multiple linear regression of $\mathrm{Y}$ over $\mathrm{X}_{1}$ and $\mathrm{X}_{2}$ is real.

In this study, for $Y, X_{1}$ and $X_{2}$, the multiple correlation coefficient $R$ is expressed

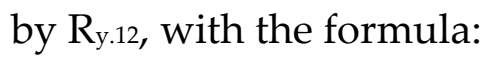




$$
R_{y .12}^{2}=\frac{r_{y 1}^{2}+r_{y 2}^{2}-2 r y_{1} r y_{2} r_{12}}{1-r_{12}^{2}}
$$

And:

$$
\begin{aligned}
& \mathrm{r}_{\mathrm{y} 1}=\frac{\sum x_{1 i} y_{i}}{\sqrt{\sum x_{1 i}^{2} \sum y_{i}^{2}}}=\text { correlation coefficient between } \mathrm{Y} \text { dan } \mathrm{X}_{1} \\
& \mathrm{r}_{\mathrm{y} 2}=\frac{\sum x_{2 i} y_{i}}{\sqrt{\sum x_{2 i}^{2} \sum y_{i}^{2}}}=\text { correlation coefficient between } \mathrm{Y} \text { dan } \mathrm{X}_{2} \\
& \mathrm{r}_{12}=\frac{\sum x_{1 i} x_{2 i}}{\sqrt{\sum x_{1 i}^{2} \sum x_{2 i}^{2}}}=\text { correlation coefficient between } \mathrm{X}_{1} \text { dan } \mathrm{X}_{2}
\end{aligned}
$$

Based on the data in table 4.44, it can be searched:

$$
\begin{aligned}
& \mathrm{r}_{\mathrm{y} 1}=\frac{\sum x_{1 i} y_{i}}{\sqrt{\sum x_{1 i}^{2} \sum y_{i}^{2}}} \\
&=\frac{116497}{\sqrt{(41142)(342505)}} \\
&=\frac{116497}{118706,95} \\
&=0,98 \\
& \mathrm{r}_{\mathrm{y} 2}=\frac{\sum x_{2 i} y_{i}}{\sqrt{\sum x_{2 i}^{2} \sum y_{i}^{2}}} \\
&=\frac{137300}{\sqrt{(57360)(342505)}} \\
&=0,98 \\
& 140164,50
\end{aligned}
$$




$$
\begin{aligned}
& \mathbf{r}_{12}=\frac{\sum x_{1 i} x_{2 i}}{\sqrt{\sum x_{1 i}^{2} \sum x_{2 i}^{2}}} \\
& =\frac{48204}{\sqrt{(41142)(57360)}} \\
& =\frac{48204}{48578,85} \\
& =0,99 \\
& R_{y .12}^{2}=\frac{r_{y 1}^{2}+r_{y 2}^{2}-2 r y_{1} r y_{2} r_{12}}{1-r_{12}^{2}} \\
& =\frac{(0,98)^{2}+(0,98)^{2}-2(0,98)(0,98)(0,99)}{1-(0,99)^{2}} \\
& =\frac{0,9604+0,9604-1,901592}{1-(0,99)^{2}} \\
& =\frac{0,019208}{1-0,9801} \\
& =\frac{0,019208}{0,0199} \\
& =0,9652
\end{aligned}
$$

From the above calculation results obtained by multiple correlation coefficients with the following interpretations:

$r_{y 1}=0.98$; it means that the relationship between variable $Y$ with variable $X_{1}$ is solid in a positive direction. This means that employee work performance is strongly influenced by training.

$r_{\mathrm{y} 2}=0.98$; it means that the relationship between variable $\mathrm{Y}$ with variable $\mathrm{X}_{1}$ is solid in a positive direction. This means that employee performance is strongly influenced by internal staffing.

$\mathrm{r}_{12}=0.99$; means that training and internal staffing have a very strong relationship. $R_{y .12}^{2}=0.9652$, meaning that the contribution of $\mathrm{X}_{1}$ and $\mathrm{X}_{2}$ to $\mathrm{Y}$ variance was $96.52 \%$; so training and internal staffing on employee performance variance have a very strong relationship. 
Furthermore, multiple regression coefficient tests, it is necessary to carry out a separate analysis of the regression coefficients, with the standard error of ai coefficient, namely:

$$
\begin{aligned}
s_{a_{1}} & =\sqrt{\frac{s_{y .12}^{2}}{\left(\sum x_{1 j}^{2}\right)\left(1-R_{1}^{2}\right)}} \\
& =\sqrt{\frac{5048,64}{(1046)(1-0,9604)}} \\
& =\sqrt{\frac{5048,64}{41,4216}} \\
& =11,04 \\
s_{a_{2}} & =\sqrt{\frac{s_{y .12}^{2}}{\left(\sum x_{2 j}^{2}\right)\left(1-R_{2}^{2}\right)}} \\
& =\sqrt{\frac{5048,64}{(1458)(1-0,9604)}} \\
& =\sqrt{\frac{5048,64}{57,7368}} \\
& =9,35
\end{aligned}
$$

with notes $\mathrm{R}_{1}=\mathrm{r}_{\mathrm{y} 2}=0.98$ and $\mathrm{R}_{2}=\mathrm{ry}_{1}=\mathrm{r}_{\mathrm{y} 2}=0.98$

then the calculated statistics:

$$
\begin{array}{r}
\mathrm{t}_{1}=\frac{a_{1}}{s_{a_{1}}}=\frac{14,74}{11,04}=1,36 \\
\mathrm{t}_{2}=\frac{a_{2}}{s_{a_{2}}}=\frac{0,08}{9,35}=0,009
\end{array}
$$

From the list of $\mathrm{t}$ distributions with $\mathrm{dk}=50-2-1=47$ and $\alpha=0.10$, it is obtained $t_{\text {table }}=1.30$. It appears that the coefficient for $X_{1}$ is meaningful, but the coefficient for $X_{2}$ is meaningless. The prediction of employee performance is the only training that makes a meaningful contribution, while internal staffing is less meaningful.

\section{E. CONCLUSION}

Based on the results of research conducted by the author in the Public Works Department of Sukabumi Regency regarding the relationship between training and 
internal staffing in improving employee performance. In general, employee responses to training make a significant contribution $\left(r_{\mathrm{y} 1}=0.98\right)$. This means that organizational analysis, job analysis, individual analysis, employee conditioning, environmental conditioning, use of learning principles can improve employee performance. Internal staffing in the form of HR planning, job characteristics, psychological aspects, knowledge, expertise, and employees $\left(r_{\mathrm{y} 2}=098\right)$. This shows that internal staffing has a powerful influence on employee performance. From the calculation of the multiple correlation coefficient between training and achievement produces a positive number that is equal to 0.98 , which means that employee work performance is strongly influenced by training. This shows that the relationship between training and employee performance is powerful. These results are supported by significant test results $t(t$ arithmetic $=1.36>=1.30)$. This means that training makes a meaningful contribution; while internal staffing $\left(t_{\text {count }}=\right.$ $0.009<t_{\text {table }}=1.30$ ) showed a less significant relationship in improving employee work performance, even though it had a correlation coefficient $\left(r_{\mathrm{y} 2}=0.98\right)$. Training and internal staffing on employee performance have a great relationship, as evidenced by a variance of $96.52 \%$. And the remaining $3.48 \%$ is caused by other factors. The author tries to provide suggestions as considerations for the Public Works Department of Sukabumi Regency. We are increasing the implementation of training and internal staffing to match the expectations of employees. Making improvements in motivating employees to be able to improve their work performance in the future, including can be done by improving training methods and internal staffing processes.

\section{REFERENCES}

1. Bernardin, H. J., \& Russel, J. E. A. (2008). Human Resources Management. New York: Mc Graw-Hill Inc.

2. Cascio, Wayne, F. (2005). Human Resources Management. Fourth Edition. New York: Mc Graw-Hill Inc.

3. Darma, A. (2000). Manajemen Prestasi Kerja. Edisi kedua. Bandung : Rajawali.

4. Dessler, G. (2012). Manajemen Personalia. Alih Bahasa Dharma Agus. Jakarta : Erlangga.

5. Dessler, G. (2013). Manajemen Personalia. Alih Bahasa Dharma Agus. Jakarta : Erlangga.

6. Flippo, E. B. (2012). Manajemen Personalia. Alih Bahasa oleh Masud. Jakarta : Erlangga.

7. Gomes, F. G. (2009). Manajemen Sumber Daya Manusia. Jogyakarta : Offset.

8. Gong, Y. (2003). Subsidiary staffing in multinational enterprises: Agency, resources, and performance. Academy of Management journal, 46(6), 728-739. 
9. Hasibuan, M. S. P. (2005). Manajemen, Dasar, Pengertian dan Masalah. Jakarta : CV Aji Masagung.

10. Husein, U. (2005). Riset Sumber Daya Manusia. Jakarta : PT. Gramedia Pustaka Utama.

11. Kim, Y., \& Ployhart, R. E. (2014). The effects of staffing and training on firm productivity and profit growth before, during, and after the Great Recession. Journal of Applied Psychology, 99(3), 361.

12. Milkovich, G.T., \& Boudreau, J.W. (2007). Human Resources Management. Boston: Richard D. Irwin. Inc.

13. Rismayadi, B. (2018). Mediasi Komitmen Organisasi Dalam Meningkatkan Kinerja Karyawan PT Perkebunan Nusantara VIII Provinsi Jawa Barat. Jurnal Manajemen \& Bisnis Kreatif, 4(1). http://doi.org/10.36805/manajemen.v4i1.386.

14. Rismayadi, B., \& Maemunah, M. (2016). Pengaruh Motivasi Kerja, Kepemimpinan dan Budaya Organisasi Terhadap Kepuasan Kerja Karyawan serta Dampaknya pada Kinerja Perusahaan (Studi kasus pada PT. Concord Indonesia). Jurnal Manajemen \& Bisnis Kreatif, 2(1). http://doi.org/10.36805/manajemen.v2i1.181

15. Sikula, A. F. (2009). Personnel Administration \& Hukum Resources Management. New York: A. Wiley Trans Edition By Jhon Wiley \& Sonsin.

16. Stevens, M. J., \& Campion, M. A. (1999). Staffing work teams: Development and validation of a selection test for teamwork settings. Journal of Management, 25(2), 207-228.

17. Sugiyono. (2017). Metode Penelitian Kuantitatif Kualitatif dan R\&D. Bandung : Alfabeta

18. Terpstra, D. E., \& Rozell, E. J. (1993). The relationship of staffing practices to organizational level measures of performance. Personnel psychology, 46(1), 27-48. 